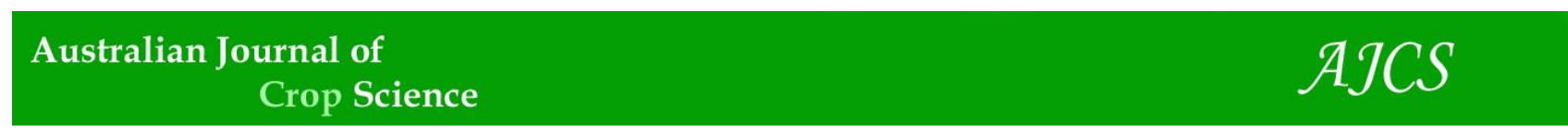

AJCS 11(08):960-967 (2017)

ISSN:1835-2707

doi: 10.21475/ajcs.17.11.08.pne445

\title{
Copper $(\mathrm{Cu})$ stress affects carbon and antioxidant metabolism in Coffea arabica seedlings
}

\section{Jacqueline Oliveira dos Santos ${ }^{1 *}$, Márcio Espinosa de Fária ${ }^{1}$, Dayane Meireles da Silva ${ }^{1}$, Helbert Rezende de Oliveira Silveira ${ }^{2}$, Cleide Nascimento Campos ${ }^{1}$, Jose Donizeti Alves ${ }^{1}$}

\author{
${ }^{1}$ Fisiologia Vegetal, Departamento de Biologia, Universidade Federal de Lavras, Lavras, Minas Gerais, Brasil \\ ${ }^{2}$ Empresa de Pesquisa Agropecuária de Minas Gerais/ EPAMIG SUL, Campus UFLA, Lavras, Minas Gerais, \\ Brasil
}

*Corresponding author: jack_oliver3@hotmail.com

\begin{abstract}
Although copper is a micronutrient essential for the normal development of plants, both insufficient and supra optimal doses can disrupt the functioning of metabolism and the production of biomass. To study the biochemical and physiological impacts of deficiency and excess of copper in coffee, we treated 6-month-old seedlings of Coffea arabica L. Catuaí cultivar to three copper treatments: control $(0.03 \mathrm{ppm})$, excess $(0.12 \mathrm{ppm})$ and deficiency $(0 \mathrm{ppm})$ for 60 days. The changes in levels of photosynthetic pigments, biomass allocation, carbohydrate partitioning, antioxidant system and proline levels were evaluated. Under deficiency and excess of copper coffee seedlings showed lower levels of chlorophyll, reduction on dry weight of shoot, lower sugar levels and higher content of hydrogen peroxide. We also observed increased levels of proline and enzymatic activity of the antioxidant system, providing conditions for the reduction of oxidative stress triggered by nutritional imbalance. In general, the results showed that coffee plants invest in antioxidant defense system as an alternative to maintain redox balance when exposed to deficiency or excess copper. However, it is not effective to prevent an increase in lipid peroxidation. Authors may indicate an optimum range for application of copper in coffee.
\end{abstract}

Keywords: Antioxidant system, Proline, Carbohydrate.

Abbreviations: APX_Ascorbate peroxidase; CAT_Catalase; MDA_Malondialdehyde, SOD_Superoxide dismutase.

\section{Introduction}

Copper $(\mathrm{Cu})$ is an essential element for the plants growth. The $\mathrm{Cu}$ occurrence is related to the presence of several minerals and compounds in the soil. These copper compounds are generally complexed in the form of organic compounds with low molecular weight (Marschner, 2011). Copper acts as a cofactor for numerous enzymes involved in the cellular redox state (Cohu and Pilon, 2010). In addition that $\mathrm{Cu}$ participate as a constituent of plastocyanin, a protein that carries electrons during photosynthesis, and superoxide dismutase (SOD) an enzyme involved in detoxification of reactive oxygen species (ROS). Copper comprises one of the superoxide dismutase isoforms, $\mathrm{Cu} / \mathrm{Zn} \mathrm{SOD}$ and $\mathrm{S}$ glutathione transferase (Ravet and Pilon, 2013; Yruela, 2009). Therefore, copper is an essential micronutrient for the normal development of plants. However, infra-optimal doses of $\mathrm{Cu}$ cause symptoms of deficiency and dysfunction of various metabolic processes. On the other hand, supraoptimal doses are potentially toxic and may disrupt metabolic functioning and the production of plant biomass (De Kok et al., 2015).

In Arabidopsis thaliana copper deficiency causes symptoms of chlorosis, which is initially observed in young leaves, and may evolve necrotic lesions (Abdel-Ghany and Pilon, 2008). In Medicago sativa, copper deficiency causes reduced expression of genes associated with the cell wall (Printz et al., 2016). Plants grown under copper insufficiency show signs of depletion in electron transport chain of photosynthesis, leading to a reduction in non-photochemical electron extinction, mainly due to impairment of plastocyanin (Abdel-Ghany and Pilon, 2008).

On the other hand, copper excess triggers phenotypic changes, such as reduced root and shoot development, reduced cell viability at root ends and premature induction of root lignification (Lequeux et al., 2010). The excess copper can also be accumulated in the cell walls inducing the formation of tracheids, which in xylem vessels are related to the greater activity of the enzymes involved in lignin biosynthesis, called peroxidase (Bouaziziet al., 2011). In addition, both excess and deficiency of $\mathrm{Cu}^{2+}$ ions can induce formation of reactive oxygen species (ROS), leading to the formation of hydrogen peroxide in the cell walls, causing loosening of the cell wall (Fry et al., 2002). In addition, EROs damage the structure of the photosynthetic apparatus, causing damage to the lipid membranes, and possible extravasation of the cellular content (Yamamoto et al, 2008). High levels of copper in the cells may lead to the replacement of the $\mathrm{Mg}^{2+}$ in the center of the chlorophyll molecule, giving rise to the so-called cupric chlorophyll. Due to this low photosynthetic assimilation, there will be a reduction in sucrose synthesis and deprivation in the supply of soluble sugars to support the metabolism. These di-saccharides can be hydrolysed to hexoses and allocated to reserve organs for later use (Hammond and Whiter, 2008).

To control these imbalances caused by low photosynthetic assimilation and to maintain the cellular redox state, plants have a complex antioxidant defense system. The first line of defense is performed by the enzyme superoxide dismutase 
(SOD), which dismantles the radical $\mathrm{O}_{2}{ }^{-}$a $\mathrm{H}_{2} \mathrm{O}_{2}$ and $\mathrm{O}_{2}$. The catalase activity (CAT) converts $\mathrm{H}_{2} \mathrm{O}_{2}$ to $\mathrm{H}_{2} \mathrm{O}$ and $\mathrm{O}_{2}$ (Capaldi et al., 2015). Moreover, several others enzymes contribute to the control of damage caused by ROS, including those present in the ascorbate-glutathione cycle, such as ascorbate peroxidase (APX) (Jiménes et al., 1998). In studies with Citrus sinensis rootstocks, it was demonstrated that low and high doses of copper reflect significant increases in SOD, CAT and peroxidases activities, which evidence for increased ROS production triggered by nutritional disturbances of copper (Hipper et al., 2016). In addition to this mechanism of enzymatic defense, plants have a non-enzymatic antioxidant enzyme mechanism, involving the accumulation of organic solutes such as proline, which maintain the osmotic adjustment (Asharaf and Harris, 2004; Burritt, 2012).

Due to the global importance of coffee, studies about the physiology of this species under micronutrients deficiency and excess is lacking. In addition, there are no studies that report the adverse effects of copper deficiency or excess on the physiological and biochemical of coffee plants. The objective of this work was to understand the physiological responses of Coffea arabica L. seedlings, such as photosynthetic pigment levels, biomass allocation, carbohydrate partitioning, antioxidant system, proline levels and damage to cell membranes under conditions of deficiency and excess of copper.

\section{Results}

\section{Chlorophyll and carotenoids concentration}

Plants subjected to 0 and $0.12 \mathrm{ppm} \mathrm{Cu}$ had lower chlorophyll levels (Table 1) than control plants from the 30th day. In addition, plants exposed to 0 and $0.12 \mathrm{ppm} \mathrm{Cu}$ had 34 and 20 $\%$ less chlorophyll than control plants.

Exposure of plants to exclusion and $0.12 \mathrm{ppm} \mathrm{Cu}$ resulted in reduction of carotenoids in leaf (Table 1) from the second evaluative stage. At the 60th day, coffee plants exposed to 0 and $0.12 \mathrm{ppm} \mathrm{Cu}$ showed a decrease of 30 and $14 \%$ in the concentration of carotenoids.

\section{Dry weight accumulation}

The shoots dry weight (Fig. 1A) of plants subjected to 0 and $0.12 \mathrm{ppm} \mathrm{Cu}$ was reduced by 35 and $13 \%, 60$ days after treatments. On the other hand, the dry root weight (Fig. 1B) was unaffected by different copper concentrations.

\section{Carbohydrate concentration}

Plants subjected to 0 and $0.12 \mathrm{ppm} \mathrm{Cu}$ have shown a decrease of total soluble sugar in leaf concentrations (Fig. 2A). However, at $0 \mathrm{ppm} \mathrm{Cu}$, this reduction has occurred since the 30th day, whereas in the $0.12 \mathrm{ppm} \mathrm{Cu}$ it was observed only at 60th day. Therefore, after 60 days, plants exposed to 0 and $0.12 \mathrm{ppm} \mathrm{Cu}$ had 36 and $42 \%$ less leaf total soluble sugar than control plants. In roots of plants exposed to $0 \mathrm{ppm} \mathrm{Cu}$, a decrease in leaf levels of total soluble sugars was observed (Fig. 2B).

The foliar starch level (Fig. 2C) in plants exposed to 0 and $0.12 \mathrm{ppm} \mathrm{Cu}$ was increased in the 30th day and decreased in the 60th day. Thus, in the last experimental time, leaf starch concentration was 27 and $32 \%$ less than in control plants, respectively. On the other hand, starch levels in roots (Fig. 2D) of plants under 0 and $0.12 \mathrm{ppm} \mathrm{Cu}$ increased since 30th day, achieving in the 60th day increments of 96 and $73 \%$.

\section{Antioxidant system}

Hydrogen peroxide level was increased in leaves (Fig. 3A) and roots (Fig. 3B) of plants exposed to 0 and $0.12 \mathrm{ppm} \mathrm{Cu}$. Thus, in the last experimental time, $\mathrm{H}_{2} \mathrm{O}_{2}$ production in leaves of plants under 0 and $0.12 \mathrm{ppm} \mathrm{Cu}$ raised 50 and $29 \%$ and in roots in 64 and $20 \%$, respectively. Similar to $\mathrm{H}_{2} \mathrm{O}_{2}$ concentration, proline was increased in shoots (Fig. 3C) and roots (Fig. 3D) of plants subjected to 0 and $0.12 \mathrm{ppm} \mathrm{Cu}$.

Increases in leaf SOD activity (Table 2 ) were observed in plants exposed to 0 and $0.12 \mathrm{ppm} \mathrm{Cu}$ from the 30th day. After 60 days, this increase was $19 \%$ in plants under $0 \mathrm{ppm}$ $\mathrm{Cu}$ and $8 \%$ in those at $0.12 \mathrm{ppm} \mathrm{Cu}$. On the other hand, this raise happened from the 30th day just in roots of plants under $0.12 \mathrm{ppm} \mathrm{Cu}$, achieving an increase of $81 \%$ in plants under 0 ppm $\mathrm{Cu}$ and $18 \%$ in those under $0.12 \mathrm{ppm} \mathrm{Cu}$ at the 60th day.

CAT activity (Table 2) in leaves was unaffected by 0.12 ppm $\mathrm{Cu}$, while plants submitted to $0 \mathrm{ppm}$ showed an increment of $30 \%$ in CAT activity at the 60th day. Nevertheless, this increase was happened in the roots of plants exposed to 0 and $0.12 \mathrm{ppm} \mathrm{Cu}$ since 30th day.

Leaves of plants exposed to 0 and $0.12 \mathrm{ppm} \mathrm{Cu}$ showed an increase in APX activity (Table 2) at the 30th day. However, only plants under $0 \mathrm{ppm}$ maintained this increment in leaves APX activity until 60 days. On the other hand, the increase in APX activity was happened in roots since 30th day only for plants exposed to $0 \mathrm{ppm} \mathrm{Cu}$. At 60th day, roots of plants subjected to 0 and $0.12 \mathrm{ppm} \mathrm{Cu}$ have shown an increase of 150 and $122 \%$ in APX activity.

Lipid peroxidation (Table 2) was higher in leaves and roots of plants under 0 and $0.12 \mathrm{ppm} \mathrm{Cu}$ since 30th day. At 60th day, this increase in leaves was $177 \%$ in plants under $0 \mathrm{ppm}$ $\mathrm{Cu}$ and $26 \%$ in plants subjected to $0.12 \mathrm{ppm} \mathrm{Cu}$. On the other hand, lipid peroxidation level was increased by $79 \%$ in roots of plants under $0 \mathrm{ppm} \mathrm{Cu}$ and $172 \%$ in plants exposed to $0.12 \mathrm{ppm} \mathrm{Cu}$.

\section{Discussion}

Due to deficiency and excess copper in coffee seedlings cv. Catuaí, a significant reduction in leaf dry weight production was observed 60 days after treatment induction (Fig. 1). Inhibition of cellular metabolic processes are observed in plants subjected to copper stress, which culminate in a reduction of biomass accumulation (Dey et al., 2014; Elleuch et al., 2013; Jouili and Ferjani, 2003). In addition, growth reduction due to the inadequate supply of copper results from several physiological changes such as mitotic disturbance (Bouazizi et al., 2010), decrease in auxin synthesis (Yuan et al., 2013), reduced photosynthetic activity (Droppa et al., 1987; Henriques, 1989) and lower carbohydrate synthesis (Yruela, 2009). At the end of the experiment, decrease in leaf biomass was also accompanied by a significant reduction of soluble sugars (Fig. 2a) and starch (Fig. 2c), which may have compromised the carbon allocation to shoot from roots when compared to coffee seedlings under normal conditions. At the end of the experiment, it was observed that copper stress did not interfere in dry weight production of roots, compared to control, indicating that plant developed efficient mechanisms to support these copper concentrations.

Despite the presence of stress, the dry weight of roots was constant compared to leaves under conditions of deficiency and excess. As a result of these findings, we can associate biomass preservation in roots to the progressive accumulation of starch from 30 days after induction of treatments (Fig. 2d). 
Table 1. Effect of different copper concentrations in leaf and roots copper levels, chlorophyll and carotenoids concentration in Coffea arabica L. plants, at 0, 30 and 60 days after treatments induction. Capital letters compare treatments $(0.03,0$ and 0.12 ppm of copper) at each sampling time; lowercase effect between times (0,30 and 60 days) within each treatment. Different letters indicate significant differences with 0.05 probability.

\begin{tabular}{|c|c|c|c|c|c|}
\hline & & $\mathrm{Cu}$ ppm & & $\begin{array}{l}\text { Chlorophyll } \\
\mu \mathrm{g} \mathrm{g}^{-1} \mathrm{FW}\end{array}$ & $\begin{array}{c}\text { Carotenoids } \\
\mu \mathrm{g} \mathrm{g}^{-1} \mathrm{FW}\end{array}$ \\
\hline Days & $\mathrm{Cu} \mathrm{ppm}$ & Leaf & Root & & \\
\hline \multirow{3}{*}{0} & 0.03 & $18 \mathrm{Aa}$ & $19 \mathrm{Aa}$ & $2991 \mathrm{Ac}$ & $564 \mathrm{Ac}$ \\
\hline & 0.00 & $18 \mathrm{Aa}$ & $19 \mathrm{Aa}$ & $2991 \mathrm{Aa}$ & $564 \mathrm{Aa}$ \\
\hline & 0.12 & $18 \mathrm{Ac}$ & $19 \mathrm{Ac}$ & $2991 \mathrm{Aa}$ & $564 \mathrm{Ab}$ \\
\hline \multirow{3}{*}{30} & 0.03 & $20 \mathrm{Ba}$ & $28 \mathrm{Ba}$ & $4166 \mathrm{Aa}$ & $847 \mathrm{Aa}$ \\
\hline & 0.00 & $11 \mathrm{Cb}$ & $6 \mathrm{Cb}$ & $2951 \mathrm{Ba}$ & $551 \mathrm{Ba}$ \\
\hline & 0.12 & $28 \mathrm{Ab}$ & $62 \mathrm{Ab}$ & $2926 \mathrm{Ba}$ & $459 \mathrm{Cc}$ \\
\hline \multirow{3}{*}{60} & 0.03 & $22 \mathrm{Ba}$ & $28 \mathrm{Ba}$ & $3636 \mathrm{Ab}$ & $748 \mathrm{Ab}$ \\
\hline & 0.00 & $12 \mathrm{Cb}$ & $6 \mathrm{Cb}$ & $2402 \mathrm{Cb}$ & $526 \mathrm{Ca}$ \\
\hline & 0.12 & $42 \mathrm{Aa}$ & $107 \mathrm{Aa}$ & $2915 \mathrm{Ba}$ & $643 \mathrm{Ba}$ \\
\hline
\end{tabular}
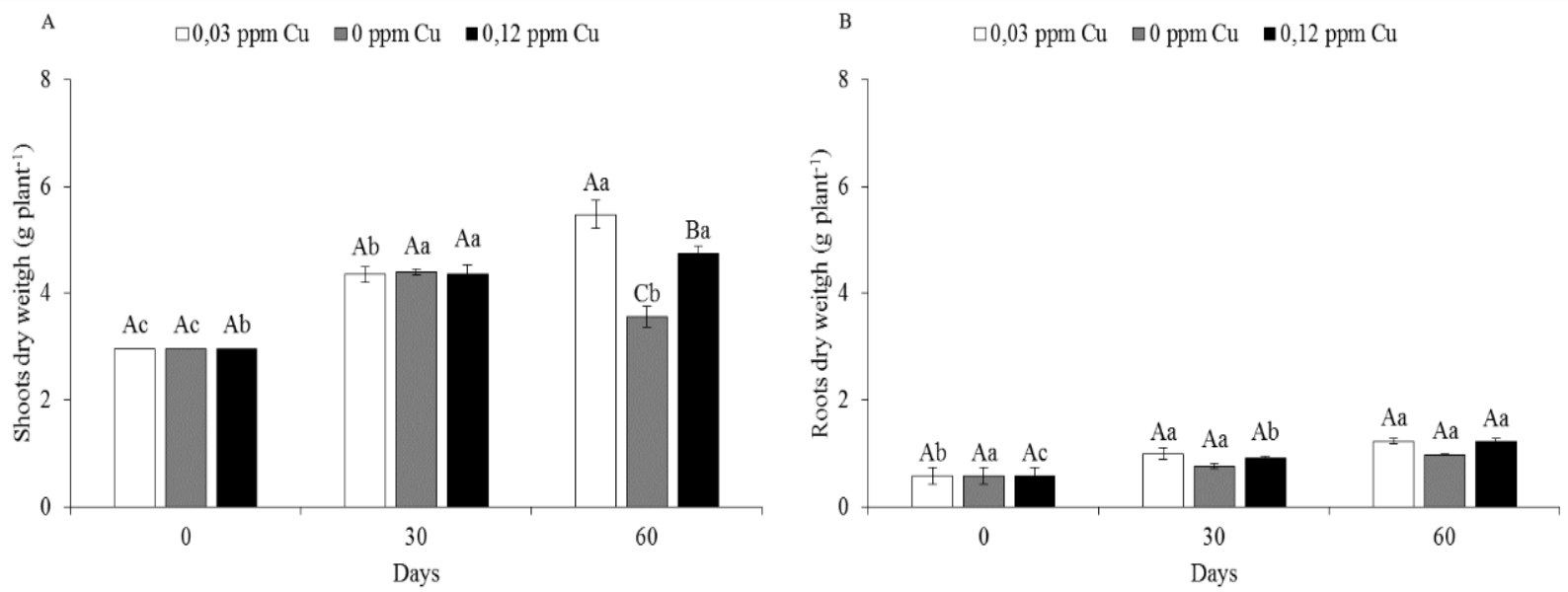

Fig 1. Effect of different copper concentrations on dry weight of shoots (A) and roots (B) of Coffea arabica L. plants. Capital letters compare treatments $(0.03,0$ and $0.12 \mathrm{ppm}$ of copper) at each sampling time; lowercase effect between times $(0,30$ and 60 days $)$ within each treatment. Different letters indicate significant differences with 0.05 probability. Bars correspond to the mean standard error.

Table 2. Effect of different copper concentrations on superoxide dismutase, catalase and ascorbato peroxidase activity and in lipid peroxidation in leaf and root of Coffea arabica L. plants. Capital letters compare treatments $(0.03,0$ and 0.12 ppm of copper $)$ at each sampling time; lowercase effect between times (0,30 and 60 days) within each treatment. Different letters indicate significant differences with 0.05 probability.

\begin{tabular}{|c|c|c|c|c|c|c|c|c|c|}
\hline \multirow[b]{2}{*}{ Days } & \multirow[b]{2}{*}{$\mathrm{Cu}$ ppm } & \multicolumn{2}{|c|}{$\begin{array}{c}\text { SOD } \\
\mathrm{U} \mathrm{mg}^{-1} \text { protein }\end{array}$} & \multicolumn{2}{|c|}{$\begin{array}{c}\text { CAT } \\
\mu \mathrm{mol} \mathrm{H}_{2} \mathrm{O}_{2} \min ^{-1} \mathrm{mg}^{-1} \\
\text { protein }\end{array}$} & \multicolumn{2}{|c|}{$\begin{array}{c}\text { APX } \\
\mu \begin{array}{c}\mu \text { molAsA min } \\
\text { protein }\end{array} \\
\mathrm{mg}^{-1} \\
\end{array}$} & \multicolumn{2}{|c|}{$\begin{array}{l}\text { Lipid peroxidation } \\
\eta m o l ~ M D A ~ g^{-1} \mathrm{FW}\end{array}$} \\
\hline & & Leaf & Root & Leaf & Root & Leaf & Root & Leaf & Root \\
\hline \multirow{3}{*}{0} & 0.03 & $1257 \mathrm{Ab}$ & $491 \mathrm{Ab}$ & $4 \mathrm{Ac}$ & $3 \mathrm{Aa}$ & $21 \mathrm{Aa}$ & $17 \mathrm{Aa}$ & $500 \mathrm{Aa}$ & $72 \mathrm{Aa}$ \\
\hline & 0.00 & $1257 \mathrm{Ac}$ & $491 \mathrm{Ab}$ & $4 \mathrm{Ab}$ & $3 \mathrm{Ab}$ & $21 \mathrm{Ab}$ & $17 \mathrm{Ab}$ & $500 \mathrm{Ac}$ & $72 \mathrm{Ac}$ \\
\hline & 0.12 & $1257 \mathrm{Ab}$ & $491 \mathrm{Ac}$ & $4 \mathrm{Ac}$ & $3 \mathrm{Aa}$ & $21 \mathrm{Aa}$ & $17 \mathrm{Ab}$ & $500 \mathrm{Ab}$ & $72 \mathrm{Ac}$ \\
\hline \multirow{3}{*}{30} & 0.03 & $1594 \mathrm{Ba}$ & $471 \mathrm{Bb}$ & $7 \mathrm{Ba}$ & $2 \mathrm{Ba}$ & $18 \mathrm{Ba}$ & $13 \mathrm{Bb}$ & $540 \mathrm{Ba}$ & $66 \mathrm{Ba}$ \\
\hline & 0.00 & $1714 \mathrm{Ab}$ & $508 \mathrm{Bb}$ & $7 \mathrm{Aa}$ & $4 \mathrm{Aa}$ & $23 \mathrm{Ab}$ & $27 \mathrm{Aa}$ & $767 \mathrm{Ab}$ & $95 \mathrm{Ab}$ \\
\hline & 0.12 & $1674 \mathrm{Aa}$ & $568 \mathrm{Ab}$ & $7 \mathrm{Ba}$ & $3 \mathrm{Aa}$ & $23 \mathrm{Aa}$ & $15 \mathrm{Bb}$ & $699 \mathrm{Aa}$ & $110 \mathrm{Ab}$ \\
\hline \multirow{3}{*}{60} & 0.03 & $1574 \mathrm{Ca}$ & $547 \mathrm{Ca}$ & $6 \mathrm{Bb}$ & $3 \mathrm{Ba}$ & $21 \mathrm{Ba}$ & $10 \mathrm{Cc}$ & $524 \mathrm{Ba}$ & $80 \mathrm{Ca}$ \\
\hline & 0.00 & $1875 \mathrm{Aa}$ & $995 \mathrm{Aa}$ & $7 \mathrm{Aa}$ & $4 \mathrm{Aa}$ & $43 \mathrm{Aa}$ & $25 \mathrm{Aa}$ & $1454 \mathrm{Aa}$ & $144 \mathrm{Ba}$ \\
\hline & 0.12 & $1703 \mathrm{Ba}$ & $645 \mathrm{Ba}$ & $5 \mathrm{Bb}$ & $4 \mathrm{Aa}$ & $21 \mathrm{Ba}$ & $22 \mathrm{Ba}$ & $662 \mathrm{Ba}$ & $218 \mathrm{Aa}$ \\
\hline
\end{tabular}



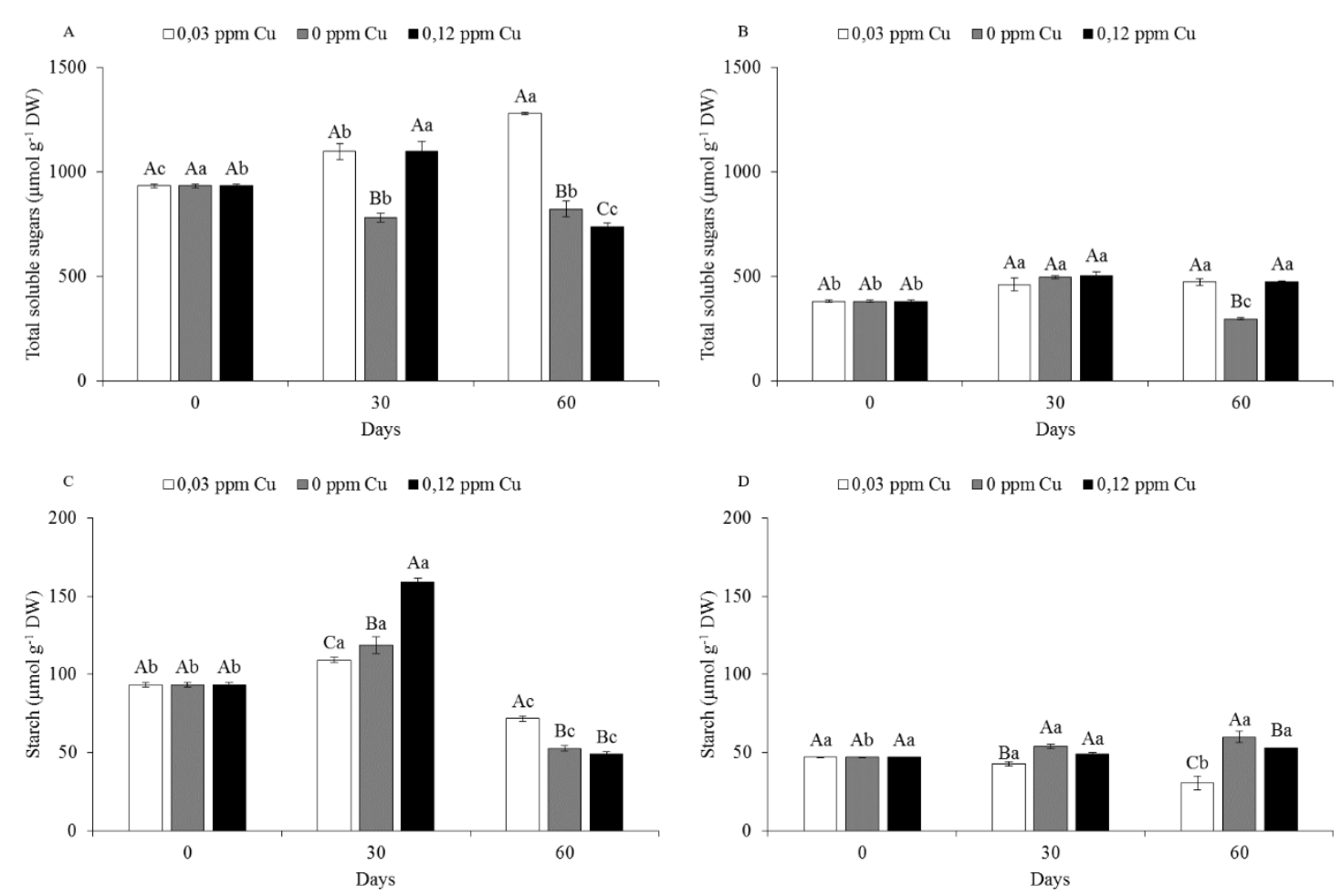

Fig 2. Effect of different copper concentrations on total soluble sugars and starch concentrations in shoots (A and C) and roots (B and D) of Coffea arabica L. plants. Capital letters compare treatments ( $0.03,0$ and $0.12 \mathrm{ppm}$ of copper) at each sampling time; lowercase effect between times $(0,30$ and 60 days) within each treatment. Different letters indicate significant differences with 0.05 probability. Bars correspond to the mean standard error.
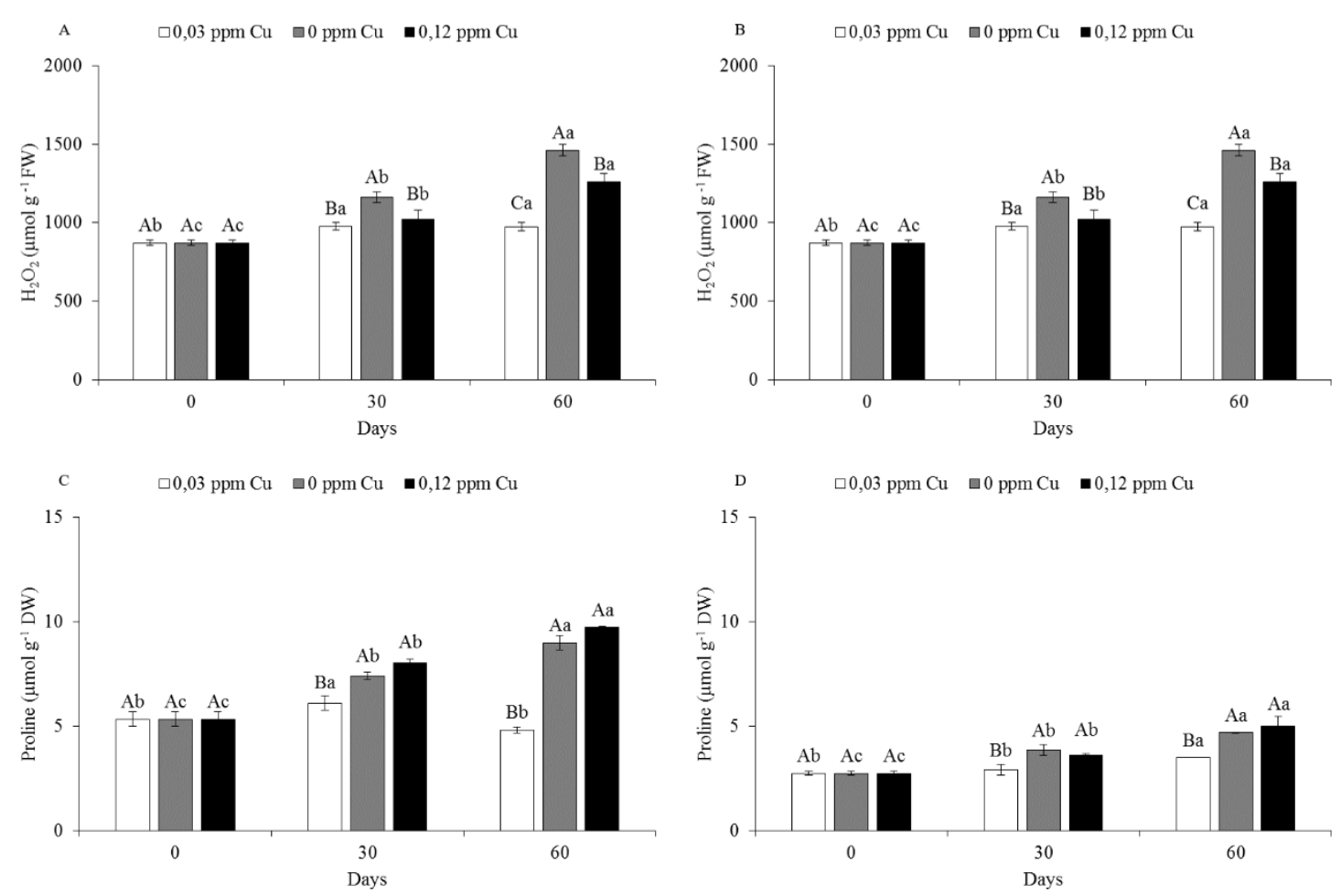

Fig 3. Effect of different copper concentrations on hydrogen peroxide and proline concentrations in shoots (A and C) and roots (B and D) of Coffea arabica L. plants. Capital letters compare treatments $(0.03,0$ and $0.12 \mathrm{ppm}$ of copper) at each sampling time; lowercase effect between times (0,30 and 60 days) within each treatment. Different letters indicate significant differences with 0.05 probability. Bars correspond to the mean standard error. 
and total soluble sugars (Fig. 2b) in plants subjected to supraoptimal doses of copper.

In Poaceae, an increase in soluble sugars content under copper stress was observed (Chai et al., 2011, 2014), suggesting the role of these molecules in cell protection. In addition, these carbohydrates are considered important organic metabolites that improve tolerance to osmotic stress and protect against photo-damage (Rodrigues-Calcerrada et al., 2011).

In leaves, chlorophyll and carotenoids levels were reduced due to deficiency and excess copper, compared to control. The results are in agreement with those observed in studies with Spartina alterniflora and Astragalusneo-mobayenii, in which a decrease in the photosynthetic pigments content induced by the increase of copper concentration (Chai et al., 2014; Karimi et al., 2012). In Hordeum vulgare L. we demonstrated that the excess of $\mathrm{Cu}^{2+}$ inhibits the chlorophyll and carotenoids biosynthesis and impairs the incorporation of these pigments into photosystems (Caspi et al., 1999). In addition to this effect, copper competes with iron uptake because it possesses a similar assimilation pathway, as it is observed a reduction in chlorophyll content due to iron deficiency induced by excess copper (Tanyolaç et al., 2007). Copper can also replace the $\mathrm{Mg}$ ion at the central position in chlorophyll molecule, leading to inhibition of chlorophyll synthesis (Yruela, 2009; Boojar; Goodarzi, 2007). Peng et al. (2013) also observed a reduction in photosynthetic pigments content under copper deficiency. Also, Droppa et al. (1987), concluded that these conditions cause a change in thylakoid membrane and modify the environment on the acceptor side of photosystems II. In addition, the reduction in pigment content is accompanied by reduction of plastoquinone synthesis.

Exposure of coffee seedlings to different copper concentrations altered cellular homeostasis, leading to higher generation of reactive oxygen species (ROS). In this sense, although higher $\mathrm{H}_{2} \mathrm{O}_{2}$ production occurred in plants with deficiency and excess copper than in control plants, $\mathrm{H}_{2} \mathrm{O}_{2}$ levels were higher in deficient plants at the end of the experiment (Fig. 2A and 2B). Similar results were observed in Phaseolus vulgaris (Bouazizi et al., 2010), Morusalba (Tewari et al., 2006), Beta vulgaris (Henriques, 1989) and Nicotiana tabacum (Raeymaeker et al., 2003). $\mathrm{H}_{2} \mathrm{O}_{2}$ acts as a signal in response to plant stress and in supra-optimal concentrations becomes toxic to membranes, affecting its permeability, which can lead to cell death (Soares et al., 2016; Capaldi et al., 2015).

Increase of ROS concentration leads to lipid peroxidation, causing membrane damage, extravasation of electrolytes, loss of protein function and ion transport channels. Malondialdehyde (MDA), a lipid peroxidation product, is considered an indicator of cellular damage under stress conditions. In spite of the increase in ROS levels, the level of MDA was increased substantially at the end of the experiment (Table 2), indicating severe damage to membranes in coffee plants exposed to $\mathrm{Cu}$ stress. Our observation is in agreement with previous reports (Thounaojam et al., 2013, Mostofa et al., 2014) suggesting that the production of ROS induced by $\mathrm{Cu}$ is the main cause of lipid peroxidation.

Generally, stress conditions due to lack or excess of nutrients in plants are related to the increase in antioxidant system activity (Li et al., 2013; Michael; Krishnaswamy, 2011; Jain et al., 2010). The increase in the detoxifying activity of enzymes of antioxidant system can be attributed, in large part, to the role of these compounds in ROS neutralization, contributing to cellular homeostatic metabolism (höller et al., 2014; Tripathi; Gaur, 2004).

In coffee seedlings, the variation of copper concentrations significantly altered SOD, CAT and APX activity in roots (Table 2). In leaves, changes in SOD levels were observed in both deficiency and excess treatments, whereas CAT and APX enzymes only changed in seedlings submitted to copper deficiency (Table 2).

Copper deficiency in coffee seedlings showed an increase in enzymatic activity of the superoxide dismutase, when compared to plants under normal copper supply. This result can be justified by the compensation of activity of other isorforms. This fact was observed in works carried on Citrus sinensis, when supplemented with low copper concentration, a lower $\mathrm{Cu} / \mathrm{Zn}-\mathrm{SOD}$, but showed an increase in $\mathrm{Mn}$-SOD activity, a mitochondrial SOD, which compensated for the reduction of $\mathrm{Cu} / \mathrm{Zn}-\mathrm{SOD}$ activity (Hipper et al., 2016).

Arabidopsis thaliana showed an increase in Fe-SOD isoform activity under the same condition. In chloroplasts, a compensation mechanism of superoxide radical elimination was observed, due to the reduction of $\mathrm{Cu} / \mathrm{Zn}-\mathrm{SOD}$ activity (Yamasaki et al., 2008).

In coffee seedlings exposed to excess copper, high SOD activity (Table 2) may be related to $\mathrm{Cu} / \mathrm{Zn}$-SOD isoform, since the cofactor for its action was in greater availability. Plants of Citrus sinensis submitted to high cupper levels showed a greater $\mathrm{Cu} / \mathrm{Zn}$-SOD and Mn-SOD activity, which was responsible by superoxide radical removal (Hippler et al., 2016).

The increase in CAT and APX activity in leaves and roots of $\mathrm{Cu}$-deficient seedlings is related to the need to neutralize the high $\mathrm{H}_{2} \mathrm{O}_{2}$ content of (Fig. 2A and 2B), avoiding possible cellular damages. Similar results were also observed in Oriza sativa L. (Dionisio-sese and Tobita 1998) and in Zea mays L. (Tanyolac et al., 2006).

However, it was observed that CAT and APX activity was maintained in coffee leaves under copper excess, and an increase in CAT and APX activity in roots under the same conditions. In studies with Ipomoea batatas L. plants, it was verified that roots was the main organ that mostly affected by the increase in copper concentration, due to a higher activity of antioxidant enzymes accompanied by the increase of $\mathrm{H}_{2} \mathrm{O}_{2}$ production (Cuchiara et al., 2015).

Another mechanism used by plant cells under stress conditions is the synthesis of low molecular weight compounds that, besides acting on osmoregulation, may present antioxidant action (Verlues; Sharma, 2010). Under these conditions, the enzymatic systems (superoxide dismutase, catalase and peroxidases) and non-enzymatic (proline, etc.) are activated. In supra-optimal copper concentration, coffee seedlings showed a significant increase in proline content (Fig 2C and 2D), which is in agreement with Silene vulgaris (Schat et al., 1997), Oriza sativa (Chen et al., 2001) and Zea mays (Wen et al., 2013). However, an interesting fact in the present study was the increase of proline levels in seedlings under copper deficiency in both leaf and root (Fig. 2C and 2D). Similar results were found in Cucumis sativus (Fariduddin et al., 2013), where proline levels were substantially increased as a result of copper deficiency. The decrease in proline levels may be due to degradation reactions of this amino acid, which are catalyzed by mitochondrial enzymes such as proline dehydrogenase in various stress conditions (Pavlikova et al., 2008; Kavi-Kishor et al., 1995). 
Materials and methods

\section{Plant culture and $\mathrm{Cu}$ treatments}

Coffea arabica L. seedlings from cultivar Catuaí 144 were cultivated for six months in $500 \mathrm{~mL}$ polypropylene bags filled with subsoil and cattle manure in 2:1 proportion, plus potassium chloride and superphosphate in the proportion 1:10 (Guimarães et al. 2002 ). After selection for uniformity in size and vigor, seedlings were transferred to $10 \mathrm{~L}$ plastic containers $(33 \times 31 \times 38-\mathrm{W} \times \mathrm{HxD})$ containing a nutrient solution (Hoagland and Arnon 1950). Plants were acclimated for 21 days when solutions with increasing concentrations were used: $1 / 4$ strength for 7 days, $1 / 2$ strength for 7 days, and full strength for 7 days. After acclimatization, seedlings were subjected to three treatments: a control, Cu-deficient and excess of copper. The original concentration of the nutrient solution was used for the control and the same solution was used for the deficient treatment, but with the exclusion of copper. For copper excess treatment, the control solution was added with the four times of recommended dose of copper nutrient. Pre-tests with different concentrations of copper were made to determine values of excess copper that presented physiological changes. The volume of the nutrient solution was replenished with deionized water on a daily basis. The $\mathrm{pH}$ of the solution was also adjusted daily to $5.5 \pm 0.5$ with $\mathrm{NaOH}$ and HCL solution $(1 \mathrm{M})$ and solutions were completely replaced weekly. All seedlings were maintained under constant aeration throughout the experimental period.

Evaluations were performed on leaves and roots at the beginning of the experiment and after 30 and 60 days. The experimental design was completely randomized using a $3 \times 3$ factorial scheme: three treatments control $(0.03 \mathrm{ppm}), \mathrm{Cu}-$ deficient $(0 \mathrm{ppm})$ and $\mathrm{Cu}$-excess $(0,12 \mathrm{ppm})$ and three times of evaluation $(0,30$, and 60 days), totaling 9 treatments with three replications. The collection times were determined from visual analysis of the plant and biochemical tests. Each experimental plot consisted of five seedlings.

Data were subjected to analysis of variance using the statistical program SISVAR 4.3 (System Analysis of Variance for Balanced Data) (Ferreira, 2011). Means between treatments were compared by the Scott and Knott (1974) test at 0.05 probability

\section{Evaluation of $\mathrm{Cu}$, chlorophyll and carotenoids}

Leaf and roots copper content was determined according Malavolta et al. (1989): $500 \mathrm{mg}$ of leaf dry weight were ground and placed in digestion tubes, to which $6 \mathrm{~mL}$ of a mix of $\mathrm{HNO}_{3}$ and $\mathrm{HClO} 4$ 2:1 (v/v) were added. The digestion tubes were then placed in a digestion block and temperature was increased gradually until $160{ }^{\circ} \mathrm{C}$ and kept until volume of the solution was reduced to half. Temperature was then increased to $210{ }^{\circ} \mathrm{C}$ and kept until white fumes of $\mathrm{HClO}_{4}$ were obtained and the extract became colorless. After cooling, the final volume was made up to $50 \mathrm{~mL}$ through the addition of deionized water. Copper content was determined through atomic absorption spectrometry.

Leaf chlorophyll and carotenoids contents were determined as described by Lichtenthaler and Buschmann (2001): $0.1 \mathrm{~g}$ of fresh weight of leaves from each treatment were macerated in $80 \%$ acetone. The final volume was made up to $10 \mathrm{~mL}$, and spectrophotometric readings were taken at 445, 645 and $663 \mathrm{~nm}$.

\section{Shoot and root dry weight}

The seedlings were divided into roots and shoots. The plant material was dried at $70{ }^{\circ} \mathrm{C}$ to constant weight and the dry weight measured.

\section{Carbohydrates}

The extraction of carbohydrates was performed according to Zanandrea et al. (2010). Starch and total soluble sugars were quantified as described by Dische (1962).

\section{Antioxidant metabolism}

$\mathrm{H}_{2} \mathrm{O}_{2}$ was determined according Velikova et al. (2000). The extract for the determination of activity of SOD, CAT and APX was obtained according to Biemelt et al. (1998). SOD activity was measured according to Giannopolitis and Ries, (1977), CAT activity was evaluated according Havir and McHale (1987) and APX activity was determined by monitoring of the rate of oxidation of ascorbate according Nakano and Asada (1981). Lipid peroxidation was determined by quantification of thiobarbituric acid reactive species, as described by Buege and Aust (1978).

\section{Proline content determination}

Proline analysis was performed according to Torello and Rice (1986) with some modifications.

\section{Conclusion}

Photosynthetic pigments shoot dry weight, total soluble sugars and starch concentration of coffee seedlings were affected by both deficiency and excess of copper at the end of experimental period. Copper stress caused an increase in hydrogen peroxide levels and consequently in lipid peroxidation, both in leaves and in roots from 30th day. Therefore, there was an activation of antioxidant metabolism as well as an increase in proline levels in both treatments of copper excess and deficiency.

\section{Acknowledgments}

Weespeciallythankto Fundação de Amparo à Pesquisa do Estado de Minas Gerais (FAPEMIG), Conselho Nacional de Desenvolvimento Científico e tecnológico (CNPq) and Coordenação de Aperfeiçoamento de Pessoal de Nível Superior (CAPES).

\section{References}

Abdel-Ghany SE, Pilon M (2008) MicroRNA-mediated systemic down-regulation of copper protein expression in response to low copper availability in Arabidopsis. J Biol Chem. 283:15932-15945.

Ashraf MPJC, Harris PJC (2004) Potential biochemical indicators of salinity tolerance in plants. Plant science, 166(1), 3-16.

Biemelt S, Keetman U, Aalbrecht G (1998) Re-aeration following hypoxia or anoxia leads to activation of the antioxidative defense system in roots of wheat seedlings. Plant Physiol. 116:651-658.

Boojar MMA, Goodarzi F (2007) The copper tolerance strategies and the role of antioxidative enzymes in three 
plant species grown on copper mine. Chemosphere. 67:2138-2147.

Bouazizi H, Jouili H, Geitmann A, El Ferjani E (2010) Cupric stress induces oxidative damage marked by accumulation of $\mathrm{H}_{2} \mathrm{O}_{2}$ and changes to chloroplast ultrastructure in primary leaves of beans (Phaseolus vulgaris L.). ActaBiol Hung. 61:191-203.

Bouazizi H, Jouili H, Geitmann A, El Ferjani E (2011) Cell wall accumulation of $\mathrm{Cu}$ ions and modulation of lignifying enzymes in primary leaves of beans seedlings exposed to excess copper. Biol Trace Elem Res. 139:97-107.

Buege JA, Aust SD (1978) Microsomal lipid peroxidation. Methods Enzymol. 52:302-310.

Burritt DJ(2012) Proline and the cryopreservation of plant tissues: functions and practical applications. In: Karkov I (ed) Current Frontiers in Cryopreservation. Intech Open Access Publisher.

Capaldi FR, Gratão PL, Reis AR, Lima LW, Azevedo RA (2015) Sulfur metabolism and stress defense responses in plants. Trop Plant Biol. 8:60-73.

Caspi V, Droppa M, Horvath G, Malkim S, Marder JB, Raskin VI (1999) The effect of copper on chlorophyll organization during greening of barley leaves. Photosynth Res. 62:165-174.

Chai MW, Liu FC, Cao D, Pan, X, Morita S, Shi FC (2011) Effects of $\mathrm{Pb}$ on physiological characteristics and $\mathrm{Pb}$ accumulation of Spartinaalterniflora. Acta Scientia Naturalium Un. 44:33-40.

Chai MW, Shi FC, Li RL, Qiu G, Liu, FC, Liu L (2014) Growth and physiological responses to copper stress in a halophyte Spartinaalterniflora (Poaceae). Acta Physiol Plant. 36:745-754.

Chen CT, Chen LM, Lin CC, Kao CH (2001) Regulation of proline accumulation in detached rice leaves exposed to excess copper. Plant Sci. 160(2), 283-290.

Cohu, CM, Pilon, M (2010) Cell biology of copper. In cell biology of metal sand Nutrients. In: Rudiger H, Mendel RR (eds). Springer. 55-74.

Cuchiara CC, Winhelamnn MC, Larré CF, Fernando JA, Braga EJB, Peters JA (2015) Physiological responses of sweet potato (Ipomoea batatasL.) plants due to different copper concentrations. Ciên Agrár. 36(6):4165-4176.

De Kok LJ, Neves MIF, Prajapati DH, Shahbaz M, Aghajanzadeh T, Stuiver CEE (2015) The significance of sulfur nutrition nand metabolism in the detoxification of excessive levels of copper, zinc and molybdenum in plants. Berichteausdem Julius Kühn-Institut. 184:4.

Dey S, Mazumder PB, Paul B (2014) Efect of copper on growth and chlorophyll content in plants (Camellia sinensis (L.) O. Kuntze). Impact J. 2(5): 223-230.

Dionisio-Sese ML, Tobita S (1998) Antioxidant responses of rice seedlings to salinity stress. Plant Sci. 135(1), 1-9.

Dische Z (1962) General color reactions. In: Whistler R L, Wolfram ML (Eds). Carbohydrate chemistry. New York: Academic Press. 477-520.

Droppa M, Masokidek J, Rozsa Z, Wolak A, Horvath LI, Farkas T, Horvath G (1987) Characteristics of $\mathrm{Cu}$ deficiency-induced inhibition of photosynthetic electron transport in spinach chloroplasts. Biochim Biophys Acta Bioenerg. 891:75-84.

Fariduddin Q, Khalil RR, Mir BA, Yusuf M, Ahmad A (2013) 24-Epibrassinolide regulates photosynthesis, antioxidant enzyme activities and proline content of Cucumis sativus under salt and/or copper stress. Environ Monitor Assess. 185(9), 7845-7856.
Ferreira DF (2011) Sisvar: computerstatisticalanalysis system. Ciênc Agrotec. 35:1039-1042.

Fry S, Miller J, Dumville J (2002) A proposed role for copperionsincellwallloosening. Plant Soil. 247:57-67.

Giannopolitis CN, Ries SK (1977) Superoxide dismutases: I., occurrence in higher plants. Plant Physiol. 59:309-314.

Guimarães RJ, Mendes ANG, Souza CAS (2002) Cafeicultura. Lavras: Editora da UFLA.

Hammond, JP, White PJ (2008) Sucrose transport in the phloem: integrating root responses to phosphorus starvation. J Exp Bot. 59(1):93-109.

Havir EA, Mchale NA (1987) Biochemical and developmental characterization of multiple forms of catalase in tobacco leaves. Plant Physiol. 84(2):450-455.

Henriques FS (1989) Effects of cooper deficiency on the photosynthetic apparatus of sugar beet (Beta vulgaris L.). J Plant Physiol. 135:453-458.

Hipper FWR, Cipriano DO, Boaretto RM, Quaggio JA, Gaziola SA, Azevedo RA, Mattos-Jr D (2016) Citrus rootstocks regulate the nutritional status and antioxidant system of trees under copper stress. Environ Exp Bot. 130:42-52.

Hoagland DR, Arnon DI (1950) The water culture method for growing plants without soil. California Agric Exp St. 347:1-32.

Höller S, Meyer A, Frei M (2014) Zinc deficiency differentially affects redox homeostasis of rice genotypes contrasting in ascorbate level. J Plant Physiol. 171(18), 1748-1756.

Jain R, Srivastava S, Solomon S, Shrivastava AK, Chandra A (2010) Impact of excess zinc on growth parameters, cell division, nutrient accumulation, photosynthetic pigments and oxidative stress of sugarcane (Saccharum spp.). Acta Physiol Planta. 32(5), 979-986.

Jiménez A, Hernández JA, Pastori G, Del Río LA Sevilla F (1998) Role of the ascorbate-glutathione cycle of mitochondria and peroxisomes in the senescence of pea leaves. Plant Physiol. 118:1327-133.

Karimi P, Khavari-Nejad A, Niknam V, Ghahremaninejad F, Najafi F (2012) The effects of excess copper on antioxidative enzymes, lipid peroxidation, proline, chlorophyll, and concentration of $\mathrm{Mn}, \mathrm{Fe}$ and $\mathrm{Cu}$ in Astragalus neo-mobayenii. Sci World J. 2012:1-6.

KaviKishor PB, Sangam S, Amrutha RN, Srilaxmi P, Naidu KR, Rao, KRSS, Rao S, Reddy KJ, Theriappan P, Sreenivasulu N (2005) Regulation of proline biosynthesis, degradation, uptake and transport in higher plants: Its implications in plant growth and abiotic stress tolerance. Curr Sci. 88:424-438.

Lequeux H, Hermans C, Lutts S, Verbruggen N (2010) Response to copper excess in Arabidopsis thaliana: impacton the root system architecture, hormone distribution, lignin accumulation and mineral profile. Plant Physiol Biochem. 48:673-682.

Li X, Yang Y, Jia L, Chen H, Wei X (2013) Zinc-induced oxidative damage, antioxidant enzyme response and proline metabolism in roots and leaves of wheat plants. Ecotox Environ Safety. 89, 150-157.

Lichtenthaler HK, Buschmann, C (2001) Chlorophylls and carotenoids: measurement and characterization by UV-VIS spectroscopy. In: WROLSTAD, R. E. et al. (Ed.). Current protocols in food analytical chemistry. Davis: John Wiley \& Sons. 1-8.

Malavolta E, Vitti GC, Oliveira AS (1989) Avaliação do estado nutricional das plantas. 2. ed. Piracicaba: FEALQ. 
Marschner H (2011) Marschner's mineral nutrition of higher plants. Academic press.

Miller GL (1959) Use dinitrosalicylic reagent acid for determination of reducing sugar. Anal Biochem. 31: 426428.

Michael PI, Krishnaswamy M (2011)The effect of zinc stress combined with high irradiance stress on membrane damage and antioxidative response in bean seedlings. Environ Experiment Bot. 74, 171-177.

Mostofa M G, Seraj ZI, Fujita M (2014) Exogenous sodium nitroprusside and glutathione alleviate copper toxicity by reducing copper uptake and oxidative damage in rice (Oryza sativa L.) seedlings. Protoplasma. 251(6), 13731386.

Nakano Y, Asada K (1981) Hydrogen peroxide is scavenged by ascorbato specific peroxidase in spinach chloroplasts. Plant Cell Physiol. 22: 867-880.

Pavlíková D, Pavlík M, Staszková L, Motyka V, Száková J, Tlustoš P, Balík J (2008) Glutamate kinase as a potential biomarker of heavy metal stress in plants. Ecotox Environ Safety. 70(2), 223-230.

Peng H, Kroneck PMH, Kupper H (2013) Toxicity and deficiency of copper in Elsholtzia splendens affect photosynthesis biophysics, pigments and metal accumulation. Environ Sci Technol. 47:6120-6128.

Printz B, Guerreiro G, Sergeant K, Audinot JN, Guignard C, Renaut J, Lutts S, Hausman, JF (2016) Combiningomicstounravel the impact of copper nutrition on alfalfa (Medicago sativa) stem metabolism. Plant Cell Physiol. 57:407-422.

Ravet K, Pilon M (2013) Copper and iron homeostasis in plants: the challenges of oxidative stress. Antioxid Redox Signal. 19:919-932.

Raeymaekers T, Potters G, Asard H, Guisez Y, Horemans N (2003) Copper-mediated oxidative burst in Nicotiana tabacum L. cv. Bright Yellow 2 cell suspension cultures. Protoplasma. 221:93-100

Schat H, Sharma SS, Vooijs R (1997) Heavy metal induced accumulation of free proline in a metal tolerant and a nontolerant ecotype of Silene vulgaris. Physiol Planta. 101(3), 477-482.

Scott AJ, Knott MA (1974) Cluster analysis method for grouping means in the analysis of variance. Biometrics. 30(3):507-512.

Soares C, Souza A, Pinto A, Azenha M, Teixeira J, Azevedo RA, Fidalgo F (2016) Effect of 24-epibrassinolide on ROS content antioxidant system, lipid peroxidation and $\mathrm{Ni}$ uptake in Solanumnigrum L. under Ni stress. Environ Exp Bot. 122:115-125.

Tanyolaç D, Ekmekci Y, Ünalan S (2007) Changes in photochemical and antioxidant enzyme activities in maize (Zea mays L.) leaves exposed to excess copper. Chemosphere. 67:89-98.

Tewari RK, Kumar P, Sharma PN (2006) Antioxidant responses to enhanced generation of superoxide anion radical and hydrogen peroxide in the copper-stressed mulberry plants. Planta. 223(6), 1145-1153.

Thounaojam TC, Panda P, Mazumdar P, Kumar D, Sharma GD, Sahoo L (2012) Excess copper induced oxidative stress and response of antioxidants in rice. Plant Physiol Biochem. 53:33-39.

Torello WA, Rice LA (1986) Effects of $\mathrm{NaCl}$ stress on proline and cation accumulation in salt sensitive and tolerant turfgrasses. Plant Soil. 93:241-247.

Tripathi B N, Gaur JP (2004) Relationship between copperand zinc-induced oxidative stress and proline accumulation in Scenedesmus sp. Planta. 219(3), 397-404.

Velikova V, Yordnov I, Edreva A (2000) Oxidative stress and some antioxidant systems in acid rain-treated bean plants: protective role of exogenous polyamines. Plant Sci. 151(1): 59-66

Verslues PE, Sharma S (2010) Proline metabolism and its implications for plant-environment interaction. Arabidopsis Book 8, 0140. 10.1199/tab.0140.

Yamamoto Y, Aminaka R, Yoshioka M, khatoon M, komayama K, Takenka D, Yamashita A, Nijo N, Inagawa K, Morita N, Sasaki T, Yamamoto Y (2008) Quality control of photosystem II: impact of light and heat stresses. Photosynth Res. 98:589-608.

Yamasaki H, Pilon M, Shikanai T (2008) How do plants respond to copper deficiency? Plant Signal Behav. 3:231232.

Yruela I (2009) Copper in plants: acquisition, transport and interactions. Funct Plant Biol. 36(5):409-430.

Yuan HM, Xu HH, Liu WC, Lu YT (2013) Copper regulates primary root elongation through PIN1-mediated auxin redistribution. Plant Cell Physiol. 54:766-778.

Wen JF, Gong M, Liu Y, Hu JL, Deng MH (2013) Effect of hydrogen peroxide on growth and activity of some enzymes involved in proline metabolism of sweet corn seedlings under copper stress. ScientiaHort. 164, 366-371.

Zanandrea I, Alves JD, Deuner S, Goulart PFP, Henrique, PC, Silveira NM (2010) Tolerance of Sesbaniavirgata plants to flooding. Aust J Bot. 57:661-669. 